\title{
ホットプレス
}

住友重機械工業(侏)岡山機械事業部技術部 矢 野 正 時

\section{Hot Pressing}

\author{
Tadatoki Yano \\ Okayama machinery division, SUMITOMO HEAVY INDUSTRIES, LTD.
}

\begin{abstract}
Conventional dewatering techniques are close to their maximum potential since they lead to longer and longer paper-machines. In a bid to reduce capital and operating costs, researchers are exploring new techniques such as impulse drying, press drying and hot pressing. The author describes techniquies, and the obstacles to their transfer to commercial practice. He concludes, that, in the short term, pressing efficiency will be improved by a stepwise increase in pressing temperature.
\end{abstract}

\section{1.はじめに}

現在，製紙産業は世界的規模で今までに経験した事 の無い不況の嵐にさらされている。このような状況下 で稼動中の抄紙機並びに今後, 新設される抄紙機に求 められる姿は次の 2 点に集約されるであろう。

(1) 初期投資（設備費用）が少ない抄紙機

(2) 運転コストの低い抄紙機

一方, 現状の抄紙機において, これらの目標達成を 妨げている最大のポイントはドライヤーパートにある。 即ち, 抄紙機の高速化に伴いドライヤーパートはます ます長くなり, その結果, 建屋も長大化の一途をたど ると共に, 運転コストの内, 大きな部分を占めるドラ イヤーパートの蒸気コストも比例的に高くなっている。 このドライヤパートのコストを下げる為, 現在, 各 種の研究がなされており，その主なものとしてインパ ルスドライング, プレスドライング及びホットプレス 等がある。

インパルスドライングはロール表面温度を150〜 $500^{\circ} \mathrm{C}$ の高温に加熱し, ニップ圧力 $30 \sim 60 \mathrm{~kg} / \mathrm{cm}^{2}$ の 下で乾燥・脱水させる方法であり, 現在のプレス・ニ ップ脱水とドライヤーにおける乾燥・脱水を同時に行 わせるものである。

プレスドライングは $0.1 \sim 1.0 \mathrm{~kg} / \mathrm{cm}^{2}$ の圧力の下 で $100^{\circ} \mathrm{C}$ 以上の温度で乾燥・脱水させる方法であるが, その乾燥過程はインパルスドライングよりは紙にとっ て優しいと言われている。ある報告によれば，現状の 蒸気シリンダに扔ける乾燥に比較し，20 倍の乾燥能
力があるとも言われている。

ホットプレスは現状のプレスニップ部において, 紙 料温度を上昇させる事により, 紙料中の水分の粘度を 下げると共に，パルプ纎維の弾性を下げニップ脱水能 力を向上させる方法である。

これらの方法の内，インパルスドライング及びプレ スドライングは顕著な脱水効果を示しているが，あく までも実験での結果であり，実機に採用するにはまだ 多くの問題点をかかえている。

本報では現在すでに実機に採用され，その効果が確 認されているホットプレスに関して以下に紹介する。

\section{2. ホットプレス}

現状のプレスで用いられているロールニップによる 脱水はほぼ能力の限界に達している。その原因は口ー ルニップでの基本的脱水メカニズム（ニップ中央で急 激にニップインパルスが上昇する）に起因している。 現状のロールニップによる脱水方法を採用する限り， 今後の高速抄紙機においてドライヤーパートの負荷は 低減する方向とは逆に増加する事が目に見えている。

一方, 現状のロールニップ脱水において, スチーム ボックスを使用することにより, プレス後のドライネ スが上昇する事はよく知られている。これは, スチー ムボックスを使用する事により, 紙料温度が上昇し紙 料内水分の粘度が下がる事によって, 水分が活性化す ると共に表面張力が低下して水分が脱水され易くなる 為である。また, 同時にパルプ纎維のヤング率が低下 し, 高ニップがかけられるようになる（一方，ヤング 
率の高い繊維，変形しにくい繊維の場合は低いニップ 圧により，繊維の結合が外れ断紙になるケースがあ る)。

この紙料の特性に着目し，機械的構造（ロールニッ プ構造）は現状のままで, 脱水能力を向上させたのが ホットプレスである。ホットプレスによる脱水におい ては, 後述する様にニップインパルス（ニップ部での 脱水圧力）は現状と同一であっても，その脱水能力は 上昇しプレス出口でのドライネスも上昇する。

ホットプレスは上述のスチームボックスにより紙料 温度を上昇させると共に，ロールニップ脱水の中心的 な存在であるセンターロールを加温し， ロール表面温 度を上昇させる事により紙料の被脱水能力を向上させ たものである。

\section{3. テスト結果及び実機での抄造結果}

\section{1 パイロットプレスでのテスト結果}

パイロットプレスはシングルフェルトで加圧用とし てトップロールに誘導加熱設備を持ち, 紙のプレヒー ト用としてスチームボックスを備えている。温度計測 の為，ロールカバーに熱電対を埋め込み，ニップ圧力 計測用としてピエゾ式圧力変換器を使用している。

（1）上質紙でのテスト結果（図 1，2）

・坪 量 $\quad: 65 \mathrm{~g} / \mathrm{m}^{2}$

・通紙速度 : : 10 350 mpm

・ ロール表面温度 : $20^{\circ} \mathrm{C} \sim 250^{\circ} \mathrm{C}$

(1) 図 1 に示す椂にロール表面温度が $20^{\circ} \mathrm{C} \sim 140^{\circ} \mathrm{C}$ までは紙料密度は緩やかに上昇し， $180^{\circ} \mathrm{C} て ゙$ 急激 に減少した。これは，この温度において紙層が分

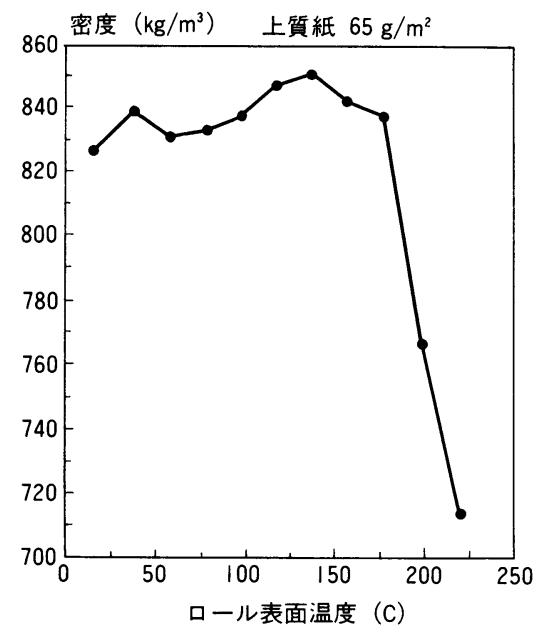

図 1 ロール表面温度一密度関係図 (パイロットプレスによるテスト結果)
離した為である。

(2) 図 2 に示寸様に Z 方向強度も $140^{\circ} \mathrm{C}$ までは緩や かに上昇し， $180^{\circ} \mathrm{C}$ で急激に低下し， $200^{\circ} \mathrm{C}$ では “零”になっている。この結果からも $180^{\circ} \mathrm{C} 〜$ $200^{\circ} \mathrm{C}$ の間で紙層が分離している事が分る。

（2）新聞用紙でのテスト結果（図 3，4）

$$
\text { ・坪 量 }: 45 \mathrm{~g} / \mathrm{m}^{2}
$$

・ニップ通過時間 : $60 \mathrm{~ms}$

・ロール表面温度 : $20^{\circ} \mathrm{C} \sim 200^{\circ} \mathrm{C} \quad\left(20^{\circ} \mathrm{C}\right.$ 毎に計測 $)$

・ニップ圧 $\quad: 100 \mathrm{KN} / \mathrm{m}$

(1) 図 3 に示す様に紙料密度はロール表面温度が $120^{\circ} \mathrm{C}$ までは上昇しているが， $120^{\circ} \mathrm{C}$ を超えると急

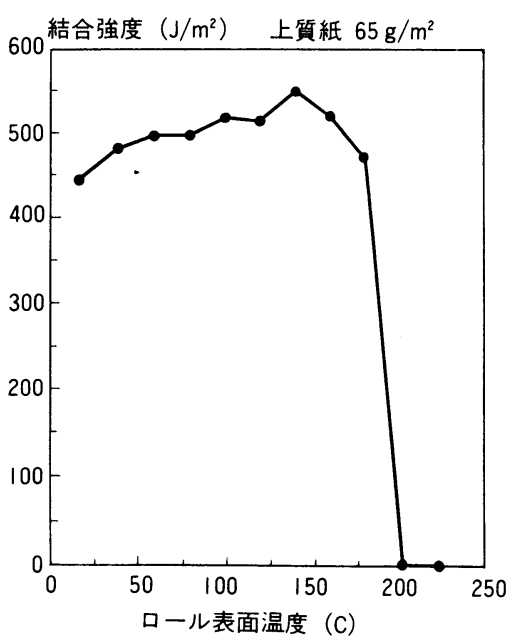

図 2 ロール表面温度一 $Z$ 方向強度関係図 (パイロットプレスによるテスト結果)

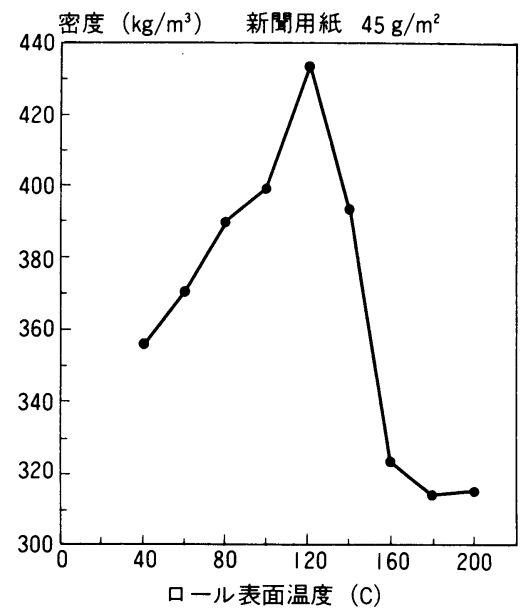

図 3 ロール表面温度一密度関係図 (パイロットプレスによるテスト結果) 


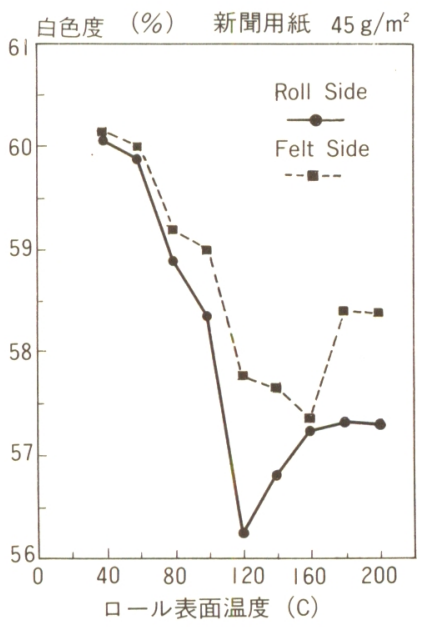

図 4 ロール表面温度一白色度関係四 (パイロットプレスによるテスト結果)

激に減少する。Z方向強度も同様に傾向を示し， $160^{\circ} \mathrm{C} \sim 200^{\circ} \mathrm{C}$ で“零”となった。

(2) 白色度はロール表面温度の上昇と共に低下し, $120^{\circ} \mathrm{C} \sim 160^{\circ} \mathrm{C}$ でも最も白色度が低くなっている。 以上のパイロットプレスでのテスト結果より，実機 でホットプレスを使用する上での下記条件が明らかと なった。

・ロール表面温度として, 紙にとっての限界温度は 上質紙で $180^{\circ} \mathrm{C}$ 前後，新聞用紙で $120^{\circ} \mathrm{C}$ 前後と考 えられる。

・ロール表面温度の上昇に伴い紙の白色度は低下寸 る。

3.2 パイロットマシンでのテスト結果

・プレス型式：シムプレスII + 4 P (図 5)
・ニップ压

$1 \mathrm{P}: 80 \mathrm{KN} / \mathrm{m}$

$2 \mathrm{P}$ : $90 \mathrm{KN} / \mathrm{m}$

$3 \mathrm{P}: 130 \mathrm{KN} / \mathrm{m}$

$4 \mathrm{P}: 150 \mathrm{KN} / \mathrm{m}$

- 加温方法

・2台のスチームボックス十七ンターロールによ る誘導加熱

・ロール表面温度 : $30^{\circ} \mathrm{C} \sim 90^{\circ} \mathrm{C}$

(1) 上質紙でのテスト結果

• 坪 量: $58 \mathrm{~g} / \mathrm{m}^{2}$

・抄 速: $15 \mathrm{~m} / \mathrm{s}(900 \mathrm{~m} / \mathrm{min})$

$3 \mathrm{P}$ 後及び $4 \mathrm{P}$ 後のドライネスは，ロール表面温度 の上昇に比例して下記の如くに変化している（図6）。

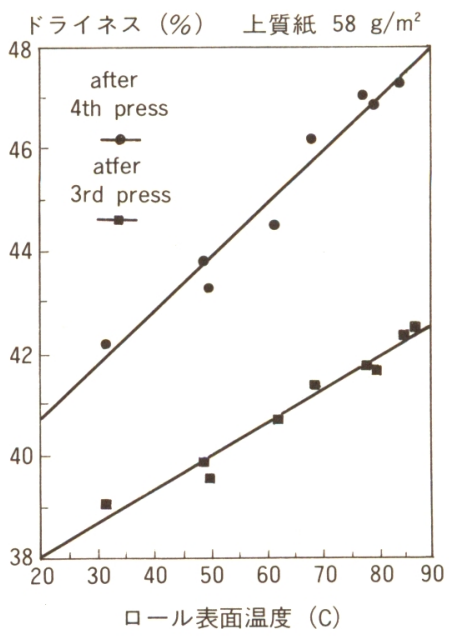

図 6 センタロール表面温度- $3 \mathrm{P}$ 及び $4 \mathrm{P}$ 後ドライ ネス関係四

(パイロットマシーンによるテスト結果)

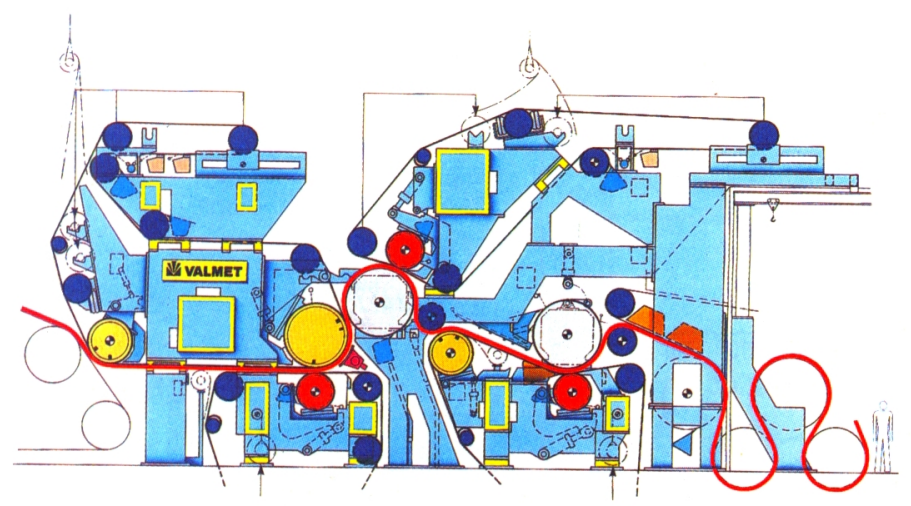

図 5 SYM-PRESS II

(WITH 4 TH PRESS) 


矢野正時

ロール表面温度 $3 \mathrm{P}$ 後ドライネス $4 \mathrm{P}$ 後ドライネス

$\begin{array}{lrr}30^{\circ} \mathrm{C} & 39 \% & 42 \% \\ 85^{\circ} \mathrm{C} & 42.5 \% & 47.5 \%\end{array}$

この結果, $3 \mathrm{P}$ ドライネスはロール表面温度が $10^{\circ} \mathrm{C}$ 上昇する毎に約 $0.6 \%$ 上昇し, $4 \mathrm{P}$ 後ドライネスは約 $1.0 \%$ 上昇している。

(2) 新聞用紙でのテスト結果

・坪 量: $45 \mathrm{~g} / \mathrm{m}^{2}$

• 抄 速: $22 \mathrm{~m} / \mathrm{s} \quad(1,320 \mathrm{~m} / \mathrm{min})$

(1) $4 \mathrm{P}$ 後のドライネスはロール表面温度の上昇に 比例して高くなっており，ロール表面温度が $10^{\circ} \mathrm{C}$ 上昇する毎に約 $1.2 \%$ ドライネスが上昇して いる(図 7)。

ロール表面温度 $4 \mathrm{P}$ 後ドライネス

$$
\begin{array}{ll}
40^{\circ} \mathrm{C} & 47 \% \\
90^{\circ} \mathrm{C} & 53 \%
\end{array}
$$

(2) ロール表面温度と紙料温度との関係は図 8 の如 くになっている。即ち, 室温においてはロール表 面温度と紙料温度はほほ等しくなっているが，口 一ル表面温度が上昇するに従い, 紙料温度はロー ル表面温度より低くなっている。ロール表面温度 が $90^{\circ} \mathrm{C}$ の時, 紙料温度は $70^{\circ} \mathrm{C}$ 前後になっている (図 8)。

(3) 紙密度もロール表面温度の上昇にほぼ比例して 高くなっており, ロール表面温度が $10^{\circ} \mathrm{C}$ 上昇する毎 に約 $20 \mathrm{~g} / \mathrm{m}^{3}$ 高くなっている（図 9)。

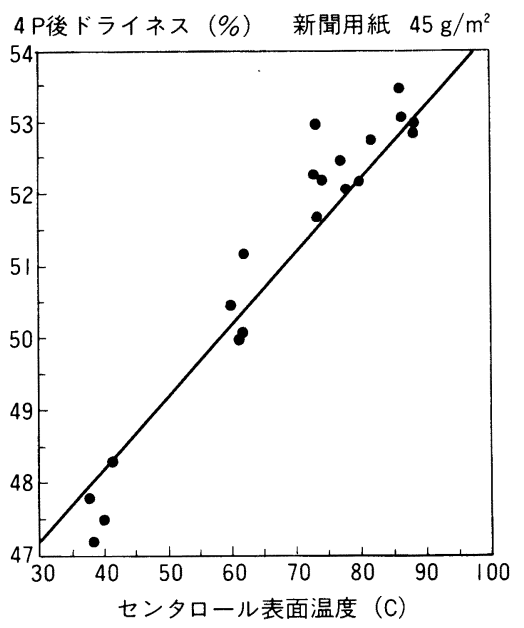

図 7 センタロール表面温度一 $4 \mathrm{P}$ 後ドライネス 関係図

抄速： $1,320 \mathrm{~m} / \mathrm{min}$ (パイロットマシーンによるテスト結果)

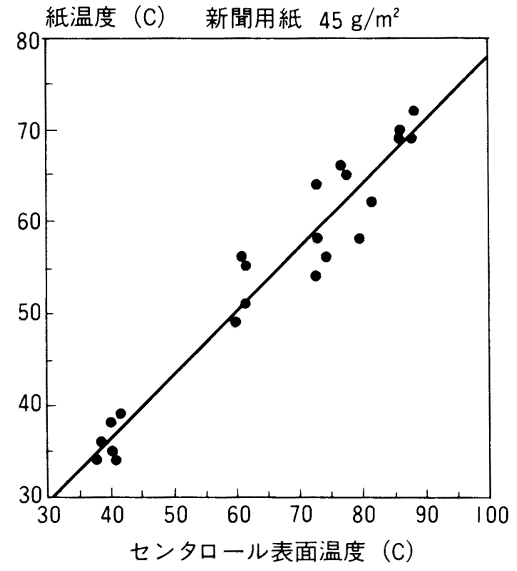

図 8 センタロール表面温度一紙温度関係図 抄速: $1,320 \mathrm{~m} / \mathrm{min}$ (パイロットマシーンによるテスト結果)

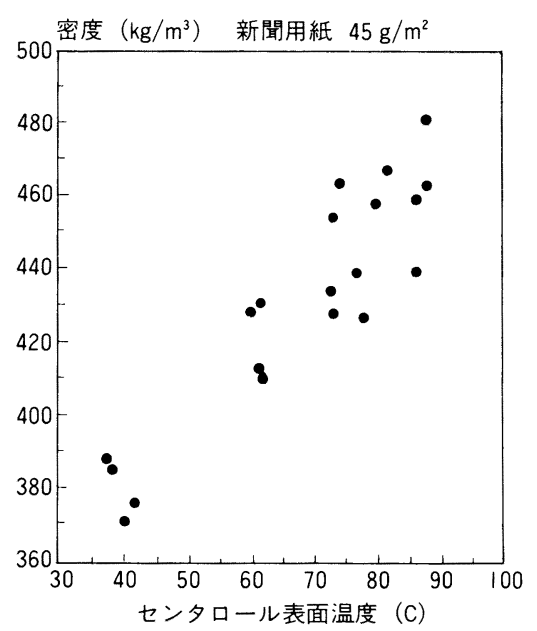

図 9 センタロール表面温度一密度関係図 抄速： $1,320 \mathrm{~m} / \mathrm{min}$ (パイロットマシーンによるテスト結果)

$$
\begin{array}{cl}
\text { ロール表面温度 } & \text { 紙密度 } \\
40^{\circ} \mathrm{C} & 380 \mathrm{~kg} / \mathrm{m}^{3} \\
90^{\circ} \mathrm{C} & 480 \mathrm{~kg} / \mathrm{m}^{3}
\end{array}
$$

(4) 有孔度 (Porosity) は紙密度の上昇（ロール表 面温度の上昇）に反比例して減少する（図 10）。

$$
\begin{array}{ccc}
\text { ロール表面温度 } & \text { 紙密渡 } & \text { 有孔度 } \\
40^{\circ} \mathrm{C} & 380 \mathrm{~kg} / \mathrm{m}^{3} & 700 \mathrm{ml} / \mathrm{min} \\
90^{\circ} \mathrm{C} & 480 \mathrm{~kg} / \mathrm{m}^{3} & 300 \mathrm{ml} / \mathrm{min}
\end{array}
$$

(5) 白色度 (Brightness) はロール表面温度の上昇 に対し反比例して低下寸る（図 11）。 


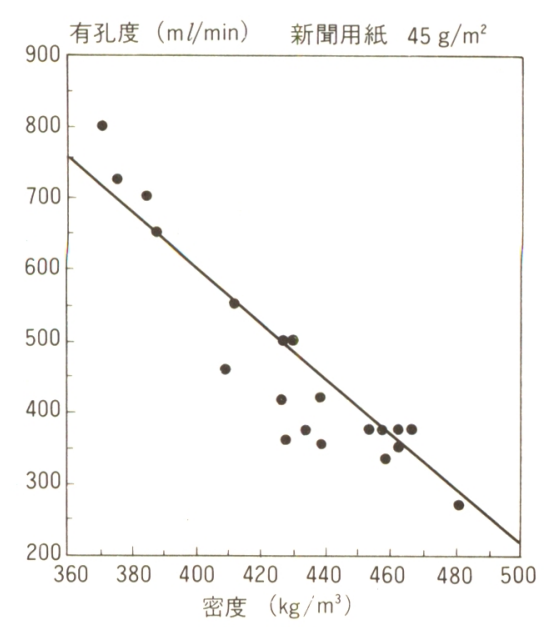

図 10 密度一有孔度関係四

抄速：1,320 $\mathrm{m} / \mathrm{min}$

(パイロットマシーンによるテスト結果)

$$
\begin{array}{cc}
\text { ロール表面温度 } & \text { 白色度 } \\
40^{\circ} \mathrm{C} & 56.5 \% \\
90^{\circ} \mathrm{C} & 53.5 \%
\end{array}
$$

以上のパイロットマシンでのテスト結果より，ホッ トプレスの使用により紙（上質紙，新聞用紙）は下記 の影響を受ける事が分った。

ロール表面温度が $10^{\circ} \mathrm{C}$ 上昇すると，4 P 後ドライネ 又は約 $1.0 \%$ 上昇する（抄速を上げると，ドライネス の上昇割合はより高くなる。抄速 $15 \mathrm{~m} / \mathrm{s} の$ 時で $1.0 \% / 10^{\circ} \mathrm{C}$ であり, $22 \mathrm{~m} / \mathrm{s}$ の時は $1.2 \% / 10^{\circ} \mathrm{C}$ とる)。 これはドライヤの乾燥負荷の 4 5\%の減少に相当す る。新聞用紙においてはドライネスの上昇に伴い密度 が上昇, 即ち, 嵩が低くなる。白色度は温度上昇と共 に低下する。

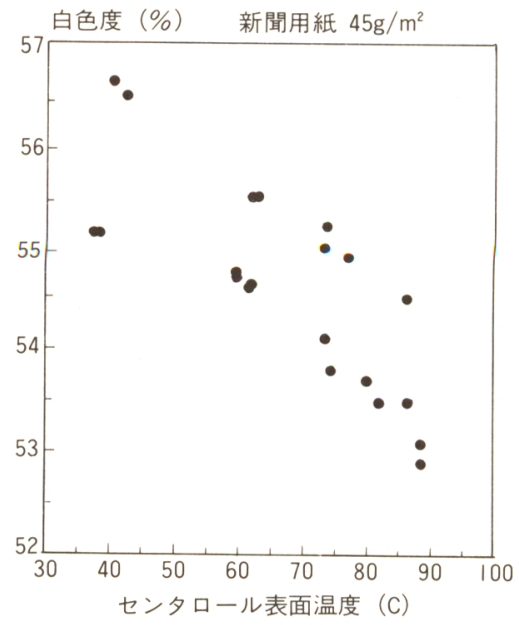

図 11 センタロール表面温度一白色度関係困 抄速 : $1,320 \mathrm{~m} / \mathrm{min}$ (パイロットマシーンによるテスト結果)

\section{3 実機での操業経験}

実機で初めてのホットプレスによる紙の抄造は‘93 年 5 月フィンランドの Voikkaa PM 11 で実施され, 抄造条件は下記の如くであった。

抄紙機：Voikkaa PM 11

プレス型式：シムプレス II（図 12）

$$
\begin{array}{ll}
\text { 紙 種 } & : \text { LWC } \\
\text { 抄 速 } & : 1,100 \mathrm{~m} / \mathrm{min} \quad(18.3 \mathrm{~m} / \mathrm{s}) \\
\text { センターロール } & : \text { VALROK HT } \quad \text { 図 } 13) \\
\text { ロール表面温度 } & : \sim 70^{\circ} \mathrm{C}
\end{array}
$$

\section{抄造結果}

(1) $3 \mathrm{P}$ 後のドライネスが $1.3 \sim 1.5 \%$ 上昇した。 この值は図 6 に示すパイロットマシンによるテス ト結果とほぼ一致している。

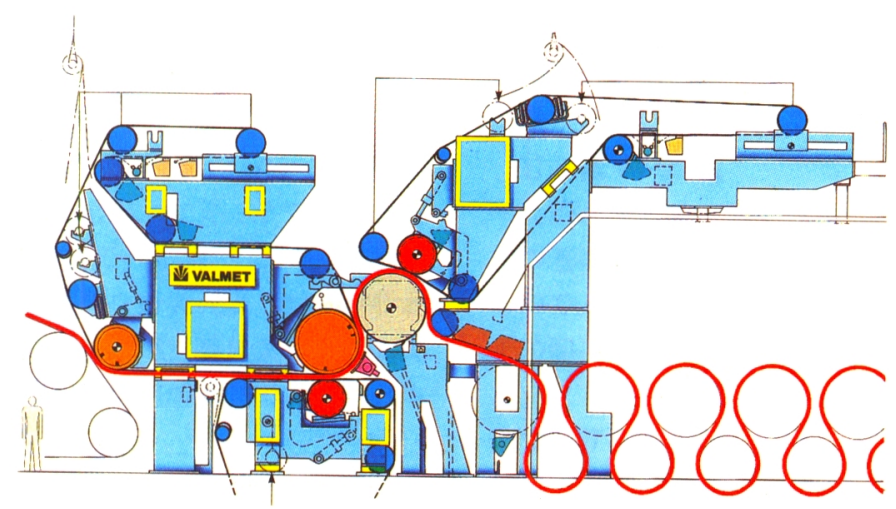

図 12 SYM-PRESS II

(WITHOUT LOADING ARMS) 


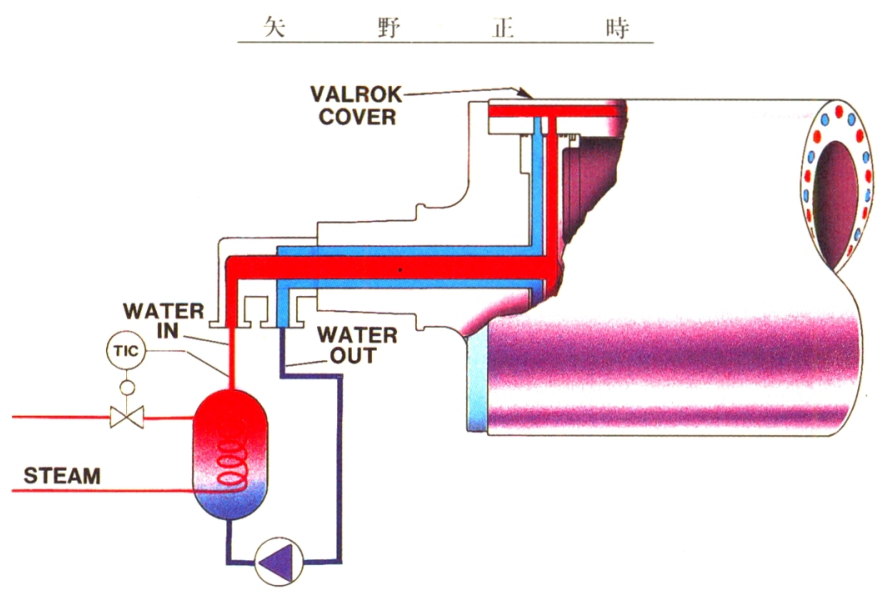

図 13 VALROK HT

HEATED PRESS CENTER ROLL

(2) 抄造速度を 5〜7\%上げる事ができた。

(3) フェルトの寿命はホットプレス使用前とほとん ど同じであった。

(4)ホットプレスにより抄造された紙は Scott Bond と平滑性に優れており, 他の品質はほぼ既 設の抄紙機によって抄造された紙と同等であった。

\section{4. 今後の抄紙機}

以上述べてきたように，各種テスト結果及び実機で の抄造結果より, ホットプレスは省エネルギー及び紙 品質の改善上効果がある事が確認できた。また, 現在 のところ, 実機でのホットプレスはパイロットマシン
よりも低い表面温度で使用されており，今後，表面温 度が高くなればより大きな効果が期待できると考えら れる。

一方, 将来, 高速抄紙機が登場することを念頭にお いて，ホットプレスをも含めたロールニッププレスと は別のプレスの開発も現在行われている。その代表的 なプレスがシュープレスである。このシュープレスに よる上質紙，新聞用紙の抄造テストがパイロットマシ ンで実施されている。

今後はこれらホットプレス，シュープレスも含めた 各種のプレスの中で, 最も高速抄紙機に適合したプレ スを見い出してゆく必要があると考えている。 